\title{
Focal Myositis in paediatric age
}

\author{
Cosimo Gigante ${ }^{1}$ \\ Marco Corradin ${ }^{2}$ \\ Rita Alaggio ${ }^{3}$ \\ 1 Paediatric Orthopaedic Unit, Padua General Hospi- \\ tal, Italy \\ 2 Department of Orthopaedic and Trauma Clinic Uni- \\ versity of Padua, Padua Hospital, Italy \\ 3 Department of Pathology, University of Padova, \\ Padua, Italy
}

\section{Corresponding author:}

Marco Corradin

Department of Orthopaedic and Trauma Clinic University of Padua, Padua Hospital

via Giustiniani 3

35128 Padua, Italy

E-mail: marco.corradin@studenti.unipd.it

\section{Summary}

Background: Focal Myositis is a rare pseudotumor of unknown aetiology that is often difficult to diagnose and treat. Typically afflicting people in adulthood, it has occasionally been reported also among children.

Purpose: the aim of this study is to review the literature of Focal Myositis in paediatric age in order to compare the clinical manifestation and the various treatment suggested by different authors. Methods: this article describes a 6 -year-old boy with focal myositis in gracilis muscle successfully treated by conservative methods, including nocturnal leg traction, intensive physiokinesi therapy and articulated knee orthosis guided to progressive extension. Furthermore a systematic review of literature concerning focal myositis in paediatric age is reported.

Conclusion: our case and the review of literature suggests that conservative methods should be the first-choice treatment for FM in paediatric age and that surgery should be strictly reserved for selected cases where non-invasive methods have previously failed.

KEY WORDS: Focal Myositis, hamstring, paediatric age.

\section{Introduction}

Focal Myositis is a rare inflammatory pseudotumor of the skeletal muscle. Its aetiology is unknown and it may be easily confused with a variety of neoplastic and inflammatory diseases ${ }^{1}$. The above-mentioned pathology tends to be more common in adulthood, and may occasionally involve the paediatric age ${ }^{2}$. Typical clinical onset is a localized painful swelling within the soft tissue of an extremity that grows insidiously over a period of several weeks with little or no pain ${ }^{1}$. There is no consensus about the treatment of focal myositis hence both surgical and conservative treatment is reported in literature. This article describes a 6-years-old boy affected by focal myositis and successfully treated by conservative methods. To our knowledge this case is one of the youngest reported without recurrence. Furthermore, literature concerning focal myositis in paediatric age was reviewed in order to compare clinical manifestation, suspected etiology and the different therapeutic approaches previously reported.

\section{Case Report}

A previously healthy 6-year-old child was admitted to our hospital due to a progressive stiffness of the left knee joint and a painful mass in the medial region of the left thigh lasting for 2 weeks. He did not practise any competitive sports and had no history of important trauma or of rheumatologic or neuromuscular disease. One week before he had upper respiratory tract infection with fever $\left(37.5^{\circ} \mathrm{C}\right)$ and cough. He presented with gait disturbance, stiff left knee (flexed at $30^{\circ}$ ), lumbar hyperlordosis and flexed ipsilateral hip joint. The child showed also marked painful hypertrophic hamstring muscles feeling hard to the touch (Fig. 1 A-B). Laboratory findings presented CPK elevated to $1374 \mathrm{UI} / \mathrm{L}$ (normal 10-200 UI/L), LD to $511 \mathrm{UI} / \mathrm{L}$ (normal 125-243 $\mathrm{UI} / \mathrm{L})$. White blood cell count and C-reactive protein (CPR) were within the normal range. Ultrasound examination was performed and showed hypertrophic hamstring medial muscle and interstitial oedema. The radiographic findings showed an increased radiopacity of soft tissue in the posterior thigh with no evidence of any bone involvement. The MRI (Fig. 2 A-B) showed an extensive alteration of the signal, oedema and marked hypertrophy of left gracilis muscle $(3 \times 3 \times 20$ $\mathrm{cm})$. On the second day of stay in our hospital an open biopsy was performed sampling numerous spec- 


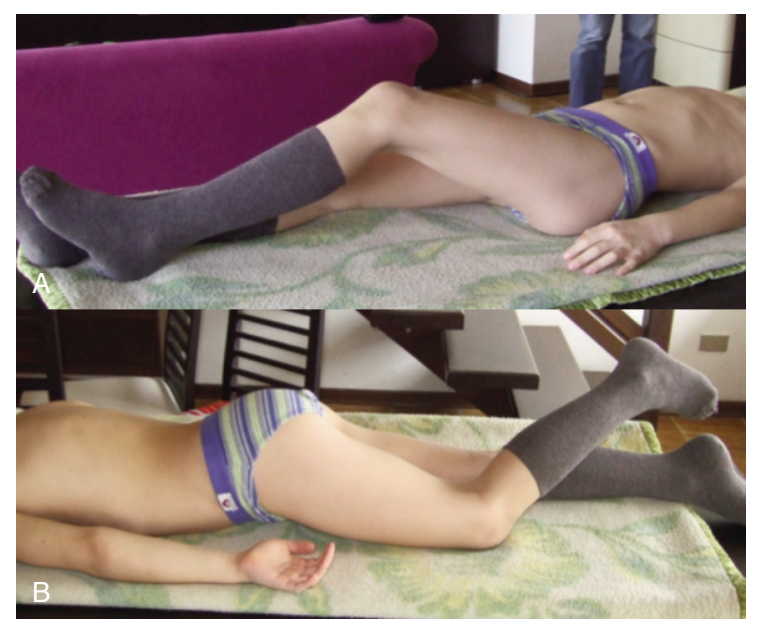

Figure $1 \mathrm{~A}-\mathrm{B}$. Patient presenting flexed contracture of the left knee.
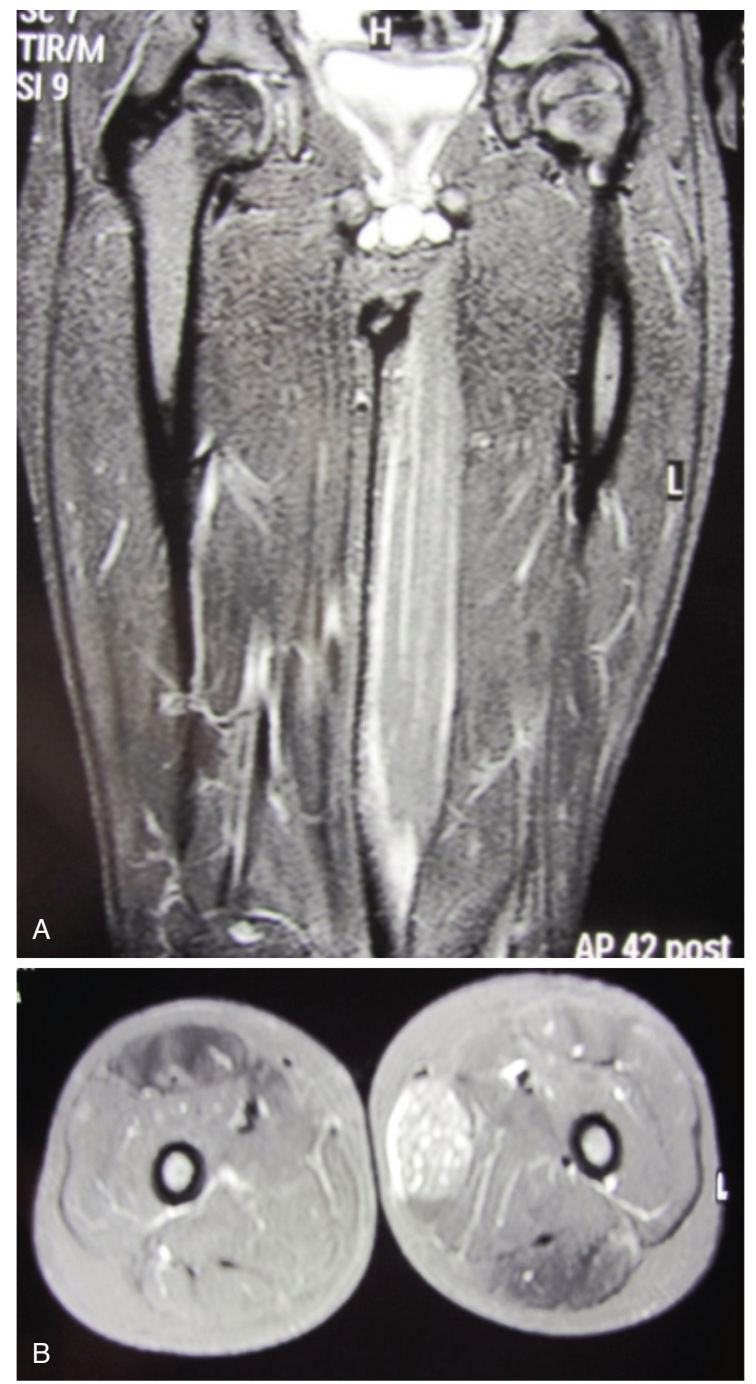

Figure $2 \mathrm{~A}-\mathrm{B}$. MRI of the calves showing the mass into the gracile muscle. imens. With hematossiline-eosine coloration it was possible to observe athropic skeletal muscle fibers of different size and focal infiltration of lymphocyte, macrophage and plasma cells, vacuolar degeneration aspect surrounded by normal muscles fibers (Fig. 3). We defined the atrophy comparing the size of the single muscle fibers with that of the uninvolved fibers at the periphery of the lesion and longitudinally oriented. When the size was substantially reduced, it was considered as atrophy. Immunohistochemical analysis of specimens (Fig. 4) showed positively to CD68 (specific for macrophage), CD3 (specific for lymphocyte), moderate positively to CD4 (specific for T-helper lyphocyte CD4+), slightly positively to CD8 (specific for cytotossic lymphocyte). Therefore, medical treatments started with repetitive infusion of Methylprednisolone $250 \mathrm{mg}$, followed by Prednisone $25 \mathrm{mg} / \mathrm{die} \mathrm{x}$ os. The pain decreased and CPK dropped to $200 \mathrm{UI} / \mathrm{I}$. The clinical course involved persistent stiffness and swelling so surgical lengthening of gracilis tendon, if necessary extended "a la carte" to the remaining medial hamstrings was prposed. Subsequently the family refused any further surgical or medical therapy. The only accepted treatment was a nocturnal skin traction at home, a cycle of intensive physiokinesi therapy with passive mobilization of the knee and a knee brace with progressive extension. After 2 months of the afore mentioned therapies there was a complete postural realignment of the left lower limb with complete resolution of the flexed contracture of knee, absence of pain, decreased hypertrophy and muscle tension (Fig. 5 A-B). No recurrence was observed within three years follow-up period.

\section{Discussion}

Focal Myositis (FM) was first described by Heffner ${ }^{1}$ in 1977 as a benign inflammatory pseudotumor of the skeletal muscles, characterized by localized painful swelling within the soft tissue of an extremity. Less

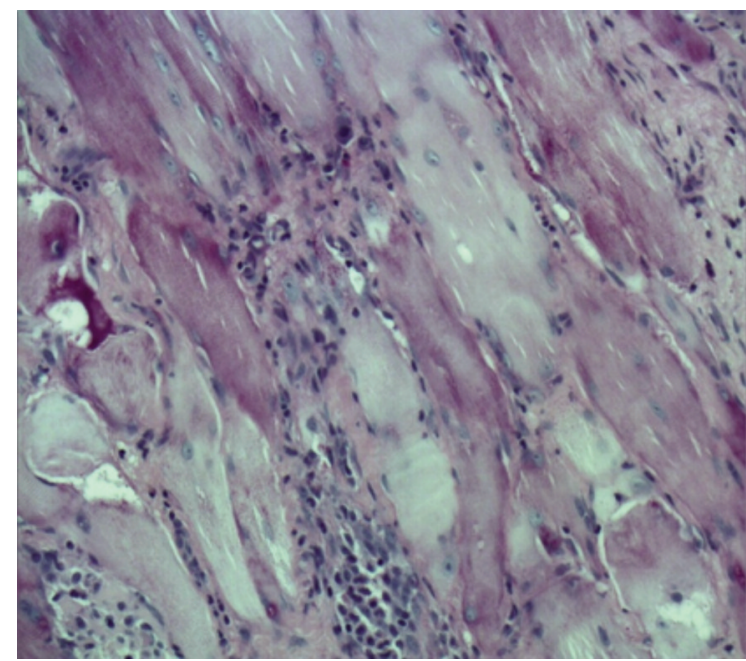

Figure 3. Microscopial examination of the sample. 


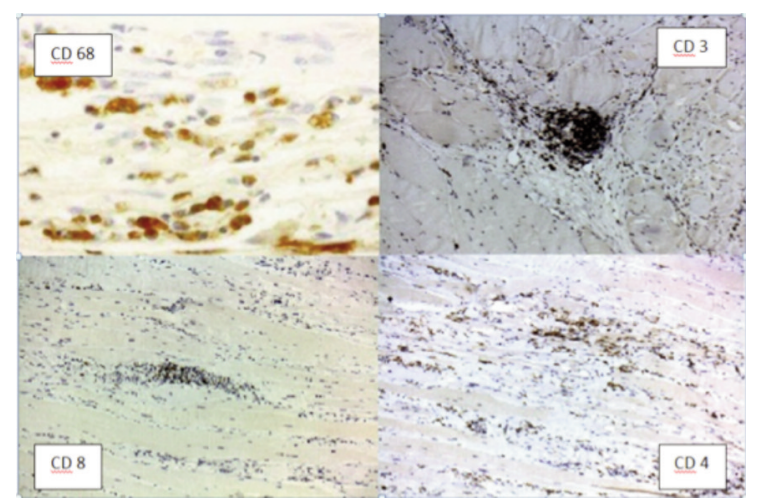

Figure 4. Immunohistochemistry of the sample.

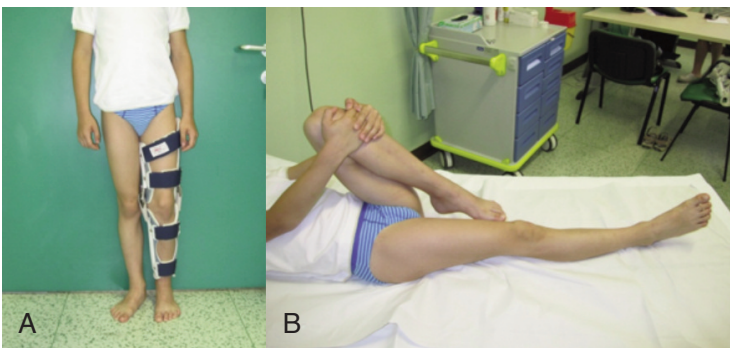

Figure 5 A-B. Patient after treatment.

commonly, this disease afflicts people in childhood. In a meta-analysis of 100 cases reported in the literature, Yanmaz ${ }^{3}$ found that $6 \%$ of the patients were less than 14 years of age, $80 \%$ were between 15 and 64 years of age, and $13 \%$ were over 65 years of age. Similarly in the largest published series of cases, Auerbach ${ }^{2}$ reviewed specimens of 115 patient with diagnosis of FM. Age ranged from 7 to 94 years (mean 41 , median 36 y) and only 2 cases were younger than 10 years of age. Clinically FM presents as swelling or enlarging of a skeletal muscle, typically moveable and unattached to the overlying intact skin with little or no pain and minimal systemic symptoms or signs, which differentiates it from an early, localised form of polymyositis ${ }^{4}$. The inferior limbs are tipically involved and FM has also been described in many other unusual sites including the tongue ${ }^{5}$, eyelid ${ }^{6}$ and oesophagus $^{7}$. Auerbach ${ }^{2}$ proposed a classification based on the extent of the muscular involvement. Involvement of part of a muscle constitutes type 1, involvement of a whole muscle constitutes type 2 , and involvement of two or more muscles in the same compartment or in adjacent compartment is classified as type 3. According to this classification our patient was classified as a type 2 FM. The literature for focal myositis reported a wide number of diseases that may be considered in the differential diagnosis such as thrombophlebitis, myositis ossificans, proliferative myositis, infections, eosinophilic fasciitis, localized nodular myositis, amyloidosis, neurogenic hypertrophy, pseudohypertrophy, dystrophies, benign soft-tissue tumour as rhambdomyoma, intramuscolar lipoma, fibromatosis, malignant entities such as rhab- domyosarcoma, leiomyosarcoma, liposarcoma, and lymphoma ${ }^{8}$. The aetiology of focal myositis is still uncertain. A previous trauma was reported in $20 \%$ of cases $^{2}$. Chronic radiculopathy was suggested as responsible for the development of neurogenic muscle hypertrophy and $\mathrm{FM}^{9}$. Recently the literature has focused on focal myositis as the result of specific environmental exposures in genetically susceptible individuals. In particularly there is little evidence that hereditary plays a role in the development of Focal Myositis. It has been reported an adult case of monozygotic twins ${ }^{10}$ and also some cases of common HLA pattern, although the same author affirmed that a large number of cases is necessary to demonstrate this relationship ${ }^{11}$. Viruses and infection were implicated in this condition, but no specific organism was identified. Toti ${ }^{12}$ tried PCR looking for EBV, herpes simplex virus types 1 and 2, and cytomegalovirus, but had negative results. Patients with focal myositis of the calf associated with chronic S1 radiculopathy were reported ${ }^{13}$. Moreover a focal myositis was reported in a woman during pregnancy ${ }^{14}$. Laboratory findings in focal myositis are reported by both normal or slightly elevated inflammation indices (white blood count, CRP, ESR) and muscle enzymes (CPK, aldolase and $\mathrm{LDH})^{15}$. MRI, important to exclude other pathologies, in FM generally reveals a diffuse swelling of the involved muscle with surrounding oedema ${ }^{15}$. At the macroscopical examination the affected muscles, compared with the normal ones, are lighter and grayish in color with dense and firm consistency. No bone formation is observed, stroma often contains fibrotic, but hemorrhage, necrosis, and myxoid changes are not observed grossly ${ }^{1}$. Biopsy and microscopically examination are fundamental for the diagnosis ${ }^{16}$. Main features are lymphocyte infiltrations into the perymysial and endomysial spaces, scattered muscles alternating fiber necrosis, regeneration and interstitial fibrosis ${ }^{2}$. Immunohistochemical studies may be helpful to assess the amount of fibrosis and to determine which types of inflammatory cells are present ${ }^{17}$. Focal myositis are reported to be macrophage-rich and T-cell-rich lesions that are replaced by B-cell and dendritic plasmacytois cells when markedly inflamed. Moreover it has been reported that in cases without severe inflammation, lymphocytes are mostly helper T- cells expressing CD3 and CD4. It is not known the impact of CD8+ Tcell cytotoxicity ${ }^{1}$. In literature there is no consensus about the most appropriate management of this pathology. Commonly Focal Myositis have been treated successfully with steroids or non-steroidal anti-inflammatory drugs (NSAIDs) ${ }^{18}$. The recurrence has been documented in approximately $18 \%$ of cases $^{3}$ and this often happens a short time after discontinuation of NSAIDs therapy. Nevertheless long-term relapses after 7 years have been reported too ${ }^{19}$. This raises the question of the appropriate duration of the conservative medical treatment. Surgical excision can be useful to remove the mass and it was performed in nearly $60 \%$ of reported cases ${ }^{19}$. Immunosuppressive or radiation therapy may be beneficial in selected 
progressive cases, although the risk of side effects ${ }^{20}$. In this study the literature of focal myositis in paediatric age was reviewed with respect to ethical international standard ${ }^{21}$. Our research was conducted on studies on Medline and Scopus resources present until March 2014 searching for the term "Focal Myositis", without language restrictions. 165 and 205 studies were present respectively. Only cases with clinical description of patients younger than 18 years old were included. Studies matching our criteria were 18 and each one described a single case of focal myositis in paediatric age ${ }^{15,22-37}$. Only 4 cases were described in the last ten years. In this retrospective analysis of literature we included also our patient so that overall 19 cases of paediatric focal myositis were reviewed. The main clinical features of each patient are reported in Table 1. The mean age was 10.9 years (range 5 months - 17 yo, median 11 yo, 11 males, 8 females). In all cases an en- larging mass that grew insidiously in a muscle was the clinical onset of the disease. Typically it was moveable and unattached to the overlying intact skin, with localized swelling. In 2 cases it was reported a gait disturbance, one with equinus deformity of the foot and one with stiff flexed knee joint (our case). Pain was present in 15 of 18 patients (83.3\%). This disease most commonly involves a single skeletal muscle (18 of the 19 patients). Only in one case the focal myositis was simultaneously present in two different sites. In 2 cases FM recurred in a different muscle, and in one of these it recurred at the same time in two different regions (calf and forearm). In 12 cases $(63.2 \%)$ the pathology involved the inferior limb (6 cases in the triceps surae muscles, 6 in the thigh region); the upper arms were afflicted in 3 cases (1 lumbrical muscle, 1 forearm, 1 left shoulder); other regions and muscles reported were: 3 cases in sternomastoid muscle, 1 in the psoas muscle,

Table 1.

\begin{tabular}{|c|c|c|c|c|c|c|c|}
\hline Author/year & age & $\begin{array}{l}\text { Location/ } \\
\text { pain }\end{array}$ & Size $(\mathrm{cm})$ & $\begin{array}{l}\text { Comorbidities/ } \\
\text { Etiology }\end{array}$ & $\begin{array}{l}\text { Laboratory } \\
\text { findings }\end{array}$ & Treatment & Outcome \\
\hline $\begin{array}{l}\text { Gigante C. } \\
\text { et al. } 2015\end{array}$ & $6 / \mathrm{M}$ & $\begin{array}{l}\text { left gracile } \\
\text { muscle/yes }\end{array}$ & $20 \times 3 \times 3$ & $\begin{array}{l}\text { Upper airway } \\
\text { tract infection }\end{array}$ & $\begin{array}{l}\mathrm{CPK} \uparrow \uparrow \\
\mathrm{LDH} \uparrow \uparrow \\
\mathrm{CPR} \leftrightarrow\end{array}$ & $\begin{array}{l}\text { Physiokinesi- } \\
\text { therapy }\end{array}$ & $\begin{array}{l}\text { No } \\
\text { recurrence }\end{array}$ \\
\hline $\begin{array}{l}\text { Binesh F } \\
\text { et al. } 2011\end{array}$ & $15 / M$ & $\begin{array}{l}\text { left vastus } \\
\text { lateralis } \\
\text { muscle/yes }\end{array}$ & $10 \times 3 \times 3$ & Negative & $\begin{array}{l}\mathrm{CPK} \uparrow \uparrow \\
\mathrm{CRP} \leftrightarrow \mathrm{I}\end{array}$ & $\begin{array}{l}\text { Cortico- } \\
\text { steroids }\end{array}$ & $\begin{array}{l}\text { No } \\
\text { recurrence }\end{array}$ \\
\hline \multirow[t]{2}{*}{$\begin{array}{l}\text { Nakane T } \\
\text { et al. } 2010\end{array}$} & $5 \mathrm{~m} / \mathrm{F}$ & $\begin{array}{l}\text { Left temporal } \\
\text { region/NR }\end{array}$ & 5 & $\begin{array}{l}\text { at } 3 \text { months } \\
\text { receive } B C G \\
\text { vaccination }\end{array}$ & $\begin{array}{l}\mathrm{CPK} \uparrow \uparrow \\
\mathrm{CRP} \uparrow\end{array}$ & Cefazolin & $\begin{array}{l}\text { Recurred } \\
\text { after } 3 \\
\text { months }\end{array}$ \\
\hline & $\begin{array}{l}\text { After } 3 \\
\text { month }\end{array}$ & $\begin{array}{l}\text { forearm, } \\
\text { bilateral soles }\end{array}$ & 2 & & $\mathrm{CPK} \uparrow \uparrow$ & Analgesics & Recovery \\
\hline $\begin{array}{l}\text { Behbahani A } \\
\text { et al. } 2007\end{array}$ & $14 / F$ & right calf/NO & $12 \times 8$ & Negative & $\begin{array}{l}\mathrm{CPK} \leftrightarrow \\
\mathrm{CRP} \leftrightarrow\end{array}$ & Excision & $\begin{array}{l}\text { No } \\
\text { recurrence }\end{array}$ \\
\hline $\begin{array}{l}\text { Ferrari D } \\
\text { et al. } 2004\end{array}$ & $13 / \mathrm{M}$ & $\begin{array}{l}\text { left } \\
\text { gastrocnocnemius } \\
\text { medialis/NO }\end{array}$ & $3 \times 2 \times 6$ & Negative & NR & Excision & $\begin{array}{l}\text { No } \\
\text { recurrence }\end{array}$ \\
\hline $\begin{array}{l}\text { Andres BM } \\
\text { et al. } 2002\end{array}$ & 3y $10 \mathrm{~m} / \mathrm{F}$ & left lateral thigh/NO & $10 \times 7$ & $\begin{array}{l}\text { Proteus } \\
\text { syndrome with } \\
\text { macrodactyly, } \\
3 \text { lipomas on } \\
\text { the chest }\end{array}$ & NR & Excision & $\begin{array}{l}\text { No } \\
\text { recurrence }\end{array}$ \\
\hline $\begin{array}{l}\text { Galloway HR } \\
\text { et al. } 2001\end{array}$ & $15 / F$ & $\begin{array}{l}\text { right vastus } \\
\text { intermediaus } \\
\text { muscle/Yes }\end{array}$ & NR & Negative & NR & NR & NR \\
\hline $\begin{array}{l}\text { Dawson JK } \\
\text { et al. } 2000\end{array}$ & $14 / F$ & left calf/yes & NR & $\begin{array}{l}\text { campylobacter } \\
\text { infections and } \\
5 \text { days of bloody } \\
\text { diarrhoea }\end{array}$ & $\begin{array}{l}\mathrm{CPK} \uparrow \uparrow \\
\mathrm{CRP} \uparrow \uparrow\end{array}$ & Analgesic & NR \\
\hline $\begin{array}{l}\text { Maheshwar } \\
\text { AA et al. } \\
2000\end{array}$ & $16 / F$ & $\begin{array}{l}\text { left } \\
\text { sternomastoid } \\
\text { muscle/yes }\end{array}$ & $6 \times 4$ & $\begin{array}{l}\text { tonsillitis } 10 \\
\text { days prior }\end{array}$ & $\begin{array}{l}\mathrm{ESR} \uparrow \\
\mathrm{CPK} \uparrow\end{array}$ & NR & $\begin{array}{l}\text { No } \\
\text { recurrence }\end{array}$ \\
\hline $\begin{array}{l}\text { Cheon JE } \\
\text { et al. } 1999\end{array}$ & $10 / \mathrm{M}$ & $\begin{array}{l}\text { anterior } \\
\text { abdomen/yes }\end{array}$ & NR & $\begin{array}{l}\text { intra-arterial } \\
\text { chemotherapy } \\
\text { for femoral } \\
\text { osteosarcoma }\end{array}$ & NR & Analgesics & Recovery \\
\hline
\end{tabular}


Table 1. (cont.)

\begin{tabular}{llllllll}
\hline Author/year & age & $\begin{array}{l}\text { Location/ } \\
\text { pain }\end{array}$ & Size $(\mathbf{c m})$ & $\begin{array}{l}\text { Comorbidities/ } \\
\text { Etiology }\end{array}$ & $\begin{array}{l}\text { Laboratory } \\
\text { findings }\end{array}$ & Treatment & Outcome \\
\hline Lorenzo- & $13 / \mathrm{M}$ & right thigh/Yes & NR & NR & all normal & Analgesics & Recovery
\end{tabular}

Sanz G.

et al. 1998

\begin{tabular}{|c|c|c|c|c|c|c|c|}
\hline $\begin{array}{l}\text { Maynié } \\
\text { M et al. } 1997\end{array}$ & $11 / \mathrm{M}$ & $\begin{array}{l}\text { left gastrocnemius } \\
\text { medialis and } \\
\text { pretibial area/yes }\end{array}$ & $\begin{array}{l}9 \times 5 \\
4 \times 2\end{array}$ & Negative & $\begin{array}{l}\mathrm{CPK} \uparrow \\
\mathrm{CPR} \leftrightarrow\end{array}$ & $\begin{array}{l}\text { Cortico- } \\
\text { steroids }\end{array}$ & $\begin{array}{l}\text { after } 1 \\
\text { year, } \\
\text { elongation } \\
\text { of achilles } \\
\text { tendon for } \\
\text { equinus } \\
\text { foot }\end{array}$ \\
\hline \multirow[t]{2}{*}{$\begin{array}{l}\text { Garcia- } \\
\text { Consuegra } \\
\text { et al. } 1995\end{array}$} & 9/M & right calf/no & 7 & $\begin{array}{l}\text { mother's sister } \\
\text { had been } \\
\text { diagnosis for LES }\end{array}$ & $\mathrm{CPK} \leftrightarrow$ & Excision & $\begin{array}{l}\text { recurred } \\
\text { after } 4 \\
\text { month }\end{array}$ \\
\hline & & & & & & $\begin{array}{l}\text { Methotrexate } \\
\text { for } 10 \text { months }\end{array}$ & Recovery \\
\hline
\end{tabular}

\begin{tabular}{|c|c|c|c|c|c|c|c|}
\hline $\begin{array}{l}\text { Naughton M } \\
\text { et al. } 1993\end{array}$ & $\begin{array}{l}\text { After } \\
2 \text { year }\end{array}$ & $\begin{array}{l}\text { left shoulder } \\
\text { and upper } \\
\text { arm/yes } \\
\text { right psoas } \\
\text { muscle/yes }\end{array}$ & NR & $\begin{array}{l}\text { Negative } \\
\text { Negative }\end{array}$ & $\begin{array}{l}\text { All normal } \\
\text { CRP } \uparrow \\
\text { CPK } \leftrightarrow\end{array}$ & $\begin{array}{l}\text { Analgesics } \\
\text { Analgesics }\end{array}$ & $\begin{array}{l}\text { No } \\
\text { recurrence } \\
\text { in this site } \\
\text { No } \\
\text { recurrence }\end{array}$ \\
\hline $\begin{array}{l}\text { Tuxen } \\
\text { et al. } 1992\end{array}$ & $17 / \mathrm{M}$ & Thigh/yes & NR & NR & NR & Analgesics & Recovery \\
\hline $\begin{array}{l}\text { Isaacson G } \\
\text { et al. } 1991\end{array}$ & $7 / \mathrm{M}$ & $\begin{array}{l}\text { sternomastoid } \\
\text { muscle/yes }\end{array}$ & NR & NR & all normal & Analgesics & Recovery \\
\hline $\begin{array}{l}\text { Maquire JK } \\
\text { JR et al. } 1988\end{array}$ & $7 / F$ & $\begin{array}{l}\text { index lumbrical } \\
\text { muscle of the } \\
\text { hand/yes }\end{array}$ & $\mathrm{NR}$ & negative & NR & Analgesics & $\begin{array}{l}\text { No } \\
\text { recurrence }\end{array}$ \\
\hline $\begin{array}{l}\text { Shapiro Mj } \\
\text { et al. } 1986\end{array}$ & $10 / F$ & Sternomastoid/yes & $3 \times 3$ & Negative & $\begin{array}{l}\mathrm{CPK} \leftrightarrow \\
\mathrm{ESR} \leftrightarrow\end{array}$ & Analgesics & NR \\
\hline Ellis GL 1979 & $11 / \mathrm{M}$ & Perioral/yes & 2.5 & Negative & NR & Excision & NR \\
\hline
\end{tabular}

Legend: NR: no reported, $\leftrightarrow:$ in normal range, $\uparrow:$ slightly elevated, $\uparrow \uparrow:$ elevated.

1 in the temporal region, 1 at the anterior abdomen, 1 at the perioral region. Masses ranged in size from 2 to $20 \mathrm{~cm}$ but only 11 of the 19 studies reported this information. A correlation with a previous recent infection was suspected in 3 cases: one patient presented a bloody-diarrhoea caused by campylobacter, the second a tonsillitis and the third an upper respiratory tract infection (our case). In 1 case FM appeared 3 months after a BCG vaccination, 1 case followed an intrarterialchemiotherapy in a patient with femoral osteosarcoma, 1 was associated to Proteus syndrome. No history of trauma was reported and only in one patient the familiar history for rheumatologic and neuromuscular disease were positive (mother who had been diagnosed with LES). No other suspected aetiologies were proposed. Laboratory examination were reported in 12 studies and in 7 of these CPK was elevated or slightly elevated, 4 had both CPK and CPR or ESR elevated and the others were reported to be in normal range. Microscopical examination was reported in 14 cases and in all of these the typical features of focal myositis likeinflamed necrotic and regenerating skeletal muscle fibers and inflammatory infiltrate including lymphocyte, macrophage, plasma cells were described. Eosinophils were observed in specimens of 2 patients. Surgical excision was performed in 5 patients $(26.3 \%)$ and in 1 of these FM recurred. This last patient was treated with immunosuppressive therapy for 10 months without any subsequent reported recurrence. The other patients were treated with analgesics and corticosteroid drugs. Two cases of this group had a recurrence of the pathology and in one case it was necessary to perform an elongation of Achilles tendon for the persistent equinus deformity of the foot. Overall in 3 of 19 patients (15.8\%) it was reported a relapse of FM.

\section{Conclusion}

This study investigated a 6-year-old child with gait disturbance and stiff flexed knee caused by focal myositis in the left gracilis muscle who had an upper respiratory tract infection, and who was successfully treated conservatively with nocturnal traction, passive physiokinesi therapy of the knee and application of a knee orthosis daily modified in progressive extension. 
By our review of the literature, focal myositis in paediatric age is a benign, inflammatory often self limiting pathology of uncertain origin. Concomitant or previous infections, that were present in the $15.8 \%$ of the patients, may be one of the specific environmental exposures that, in genetically susceptible individuals, might cause the development of this pathology. MRI, laboratory findings and microscopical examination are necessary for the diagnosis and to exclude other pathologies. The conservative treatments were successfully in 12 of 14 patients. In addition to analgesic and corticosteroid drugs, we prescribe intensive physiokinesi therapy with passive joint mobilization when stiffness and hard muscle contracture occur. The use of a splint may also be helpful in treating this problem. Although more patients are probably needed for conclusive recommendations, our case and the review of literature strongly suggests that conservative methods should be the first-choice treatment for FM in paediatric age and that surgery should be strictly reserved for selected cases where non-invasive methods have previously failed.

\section{References}

1. Heffner RR Jr, Armbrustmacher VW, Earle KM. Focal myositis. Cancer. 1977;40(1):301-316.

2. Auerbach A, Fanburg-Smith JC, Wang G, Rushing EJ. Focal myositis: a clinicopathologic study of 115 cases of an intramuscular mass-like reactive process. Am J Surg Pathol. 2009;33(7):1016-1024.

3. Yanmaz Alnigenis MN, Kolasinski SL, Kalovidouris AE. Focal myositis: a review of 100 previously published cases and a report of 2 new cases. Clin Exp Rheumatol. 1999;17(5):631.

4. Heffner RR Jr, Barron SA. Polymyositis beginning as a focal process. Arch Neurol. 1981;38(7):439-442.

5. Lee MW, Huh JR, Lee WJ, Choi JH, Moon KC, Koh JK. Focal myositis of the tongue presenting as macroglossia. Clin Exp Dermatol. 2009;34(8):e869-872.

6. Lim KL, Robson K, Powell RJ. Focal myositis: an unusual cause of bilateral upper eyelid swellings. Postgrad Med J. 1993;69(817):876-878.

7. Chiang IP, Wang J, Tsang YM, Hsiao $\mathrm{CH}$. Focal myositis of esophagus: a distinct inflammatory pseudotumor mimicking esophageal malignancy. Am J Gastroenterol. 1997;92(1):174175.

8. Smith AG, Urbanits S, Blaivas M, Grisold W, Russell JW. Clinical and pathologic features of focal myositis. Muscle Nerve. 2000;23(10):1569-1575.

9. Prutki M, Potocki K, Stern-Padovan R, Seiwerth S, LaktasicZerjavic N, Habek M. Unilateral muscle hypertrophy and focal myositis following S1 radiculopathy. J Musculoskelet Neuronal Interact. 2013;13(2):259-261.

10. Naggar EA, Kanda F, Okuda S, et al. Focal myositis in monozygotic twins. Intern Med. 2004;43(7):599-601.

11. Sekiguchi $K$, Kanda F, Oishi K, et al. HLA typing in focal myositis. J Neurol Sci. 2004;227(1):21-25.

12. Toti $\mathrm{P}$, Romano L, Villanova M, Zazzi M, Luzi P. Focal myositis: a polymerase chain reaction analysis for a viral etiology. Hum Pathol. 1997;28(1):111-113.

13. Gross R, Degive C, Dernis E, Plat M, Dubourg O, Puéchal X. Focal myositis of the calf following $S 1$ radiculopathy. Semin Arthritis Rheum. 2008;38(1):20-27.

14. Hepburn A, Damani N, Sandison A, Pandit N. Idiopathic focal myositis in pregnancy. Rheumatology (Oxford). 2000;39(2): 211-213.

15. Galloway HR, Dahlstrom JE, Bennett GM. Focal myositis. Australas Radiol. 2001;45(3):347-349.

16. Georgalas C, Kapoor L, Chau H, Bhattacharyya A. Inflammatory focal myositis of the sternomastoid muscle: is there an absolute indication for biopsy? A case report and review of the literature. Eur Arch Otorhinolaryngol. 2006;263(2):149-151.

17. Macchioni $\mathrm{P}$, Boiardi L, Meliconi R, et al. Immunohistochemical analysis of an additional case of focal myositis. Clin Exp Rheumatol. 1995;13(6):753-757.

18. Khan A, Herdman G, Srinivasan U. Acute focal myositis causing significant radiological andhistological abnormality settles spontaneously with expectant management. BMJ Case Rep. 2013.

19. Kisielinski K, Miltner O, Sellhaus B, Krüger S, Goost H, Siebert $\mathrm{CH}$. Recurrent focal myositis of the peroneal muscles. Rheumatology (Oxford). 2002;41(11):1318-1322.

20. Garcia-Consuegra J, Morales C, Gonzalez J, Merino R. Relapsing focal myositis: a case report. Clin Exp Rheumatol. 1995;13(3):395-397.

21. Padulo J, Oliva F, Frizziero A, Maffulli N. Muscles, Ligaments and Tendons Journal. Basic principles and recommendations in clinical and field science research. MLTJ. 2013;4:250-252.

22. Binesh F, Taghipour S, Navabii $\mathrm{H}$. Focal myositis of the thigh misdiagnosed radiologically as rhabdomyosarcoma. BMJ Case Rep. 2011.

23. Nakane T, Nakamura K, Hata S, Kamiya Y, Sugita K. Recurrent focal myositis in an infant: a report of the youngest case. $J$ Paediatr Child Health. 2010;46(12):785-786.

24. Behbahani A, Arkader A, Golden JA, Dormans JP. Painless unilateral calf mass in a 14-year old girl. Clin Orthop Relat Res. 2007;460:263-268.

25. Ferrari D, Bertoni F, Bacchini P, Donzelli O. Focal myositis. Description of a case and review of the literature. Chir Organi Mov. 2004;89(1):75-79.

26. Andres BM, McCarthy EF Jr, Frassica FJ. A muscular lesion suggestive of focal myositis in a child with Proteus syndrome. Clin Orthop Relat Res. 2002;(404):326-329.

27. Dawson JK, Davidson JE. Focal myositis due to Campylobacter infection. Rheumatology (Oxford). 2001;40(6):704-706.

28. Maheshwar AA, Douglas-Jones AG, Cuddihy PJ. Rapidly enlarging lump in the neck: is it atumour? J R Coll Surg Edinb. 2000;45(5):339-341.

29. Cheon JE, Kim IO, Kim WS, Yeon KM, Ahn HS, Shin HY. Abdominal-wall myositis secondary to intra-arterial chemotherapy for femoral osteosarcoma. Pediatr Radiol. 1999;29(7):546-548.

30. Lorenzo-Sanz G, Egea-Nadal P, García-Villanueva M, Gamir ML, Ocete G, García-Lacalle C. Focal myositis: report of a case in pediatric age and review of the literature. Rev Neurol. 1998;27(157):505-508.

31. Maynié M, Robert $\mathrm{H}$, Eloit $\mathrm{S}$, Arnal $\mathrm{C}$, Dolet $\mathrm{C}$. Focal myositis in children. Apropos of a case. Rev Chir Orthop Reparatrice Appar Mot. 1997;83(4):382-386.

32. Naughton M, Jessop JD, Williams BD. Idiopathic recurrent non-suppurative focal myositis: a report of two cases. $\mathrm{Br} \mathrm{J}$ Rheumatol. 1993;32(12):1101-1104.

33. Tuxen MK, Aru A. Focal myositis. Ugeskr Laeger. 1992;154 (50):3600-3602.

34. Isaacson $\mathrm{G}$, Chan $\mathrm{KH}$, Heffner RR Jr. Focal myositis. A new cause for the pediatric neck mass. Arch Otolaryngol Head Neck Surg. 1991;117(1):103-105.

35. Maguire JK Jr, Milford LW, Pitcock JA. Focal myositis in the hand. J Hand Surg Am. 1988;13(1):140-142.

36. Shapiro MJ, Applebaum H, Besser AS. Cervical focal myositis in a child. J Pediatr Surg. 1986;21(4):375-376.

37. Ellis GL, Brannon RB. Focal myositis of the perioral musculature. Oral Surg Oral Med Oral Pathol. 1979;48(4):337-341. 